\title{
Manual de psicologia jurídica
}

\author{
Fausto Eduardo Menon Pinto'
}

MIRA y LÓPEZ, Emílio (2005). Manual de psicologia jurídica. 2 ed. atualizada. Campinas: LZN. 421 p. (Tradução e notas: Ricardo Rodrigues Gama).

No século passado, Emílio Mira y López (1890-1968) foi considerado, entre seus pares, um dos pensadores de maior expressão intelectual que mais influenciaram o estudo e a disseminação de temas psicológicos por todo o mundo. Uma de suas brilhantes obras, talvez pouco divulgada no meio acadêmico, é o livro Manual de psicologia jurídica, confeccionado em capa dura e publicado pela LZN Editora, com uma coletânea de 16 (dezesseis) capítulos e mais um apêndice geral sobre a Legislação Brasileira, que visam à discussão do papel da psicologia no campo do direito. Segundo sugere o próprio autor, o objetivo do livro é fazer uma breve exposição da psicologia, no panorama do conhecimento científico, e com isso auxiliar o jurista em seu trabalho diário, quer seja nos tribunais, quer seja nas varas da infância e da família.

Logo no primeiro capítulo, faz-se um retrospecto acerca da origem da psicologia moderna, refletindo as principais linhas de pensamento psicológico, sendo elas as principais, pelo menos no caráter de publicação em livros: o condutivismo (o que se convencionou chamar de behaviorismo) e a psicanálise. $\mathrm{O}$ autor situa esse conhecimento para a área do direito, especificamente situando-o dentro da ciência do comportamento e dos processos inconscientes, discutindo, pois, os objetivos desse saber na psicologia jurídica.

No segundo capítulo, intitulado Estatística da personalidade bumana, $\mathrm{O}$ autor destaca algumas particularidades que pertencem ao estudo da psicologia geral. Entre elas, estão o temperamento, a inteligência, o sentimento, o caráter, a associação de idéias e a imaginação. É interessante notar que, na parte em que se comentam sobre os sentimentos, emoções e afetos, propõe-se uma definição em que são todos esses aspectos, ou melhor dizendo, toda a tonalidade afetiva, que dão um colorido às mais variadas idéias - inclui-se assim, até em certo ponto de vista, uma perspectiva inovadora para a ciência psicológica, ou seja, pensamentos e sentimentos como objetos indissociáveis: é um pensar sentindo.

O terceiro capítulo versa sobre a dinâmica da personalidade. $\mathrm{O}$ autor se atém a uma discussão sintética de como se processa o funcionamento do psiquismo humano. Ele parte teoricamente da infância à juventude, até o adulto, colocando em evidência elementos psicológicos presentes nas fases do desenvolvimento de cada um de nós e discutindo o papel dos mecanismos de defesa, tais como a projeção, a racionalização e a negação. Entende-se bem que só o conhecimento efetivo do modus operandi do ser humano psicológico permite ao jurista ter uma visão ampliada do ser humano, que vai muito além do corpo físico e biológico, mas que se compõe de uma alma; o qual representa uma rede associativa de significado simbólico que o indivíduo constrói mentalmente sobre si mesmo e o mundo que o cerca.

Nos quatro capítulos seguintes, por sua vez, a temática fundamental de estudo é a moralidade humana e suas respectivas aplicabilidades na esfera jurídica. Faz-se uma breve explanação acerca das teorias da moral, abrangendo no debate a clássica concepção teórica do epistemólogo genebrino Jean Piaget e também o conceito de dever e justiça. Isso serve de pano de fundo para o entendimento do que se chama de psicologia do delito, ou simplesmente as possíveis motivações inconscientes que levariam uma pessoa a cometer um ato contra o patrimônio público ou um cidadão, por exemplo. Percebe-se, como análise do autor, que toda ação delituosa condiz, na verdade, como uma representação complexa no nível psíquico do que significam as reais intenções do agressor.

No oitavo, nono e décimo capítulos o autor se apóia na descrição do dia-a-dia do judiciário, em particular no papel da psicologia aplicada. Destaca a importância da psicoterapia do testemunho, da mesma forma que os meios para obtenção da evidência de prova, ambos importantes para a coleta de material no trabalho de defesa do advogado. Complementando isso, a influência da personalidade do réu na hora do testemunho é, por demais, cogente no tocante à análise e decisão de um tribunal de júri. A título de ilustração, uma personalidade histérica pode se valer de testemunhos falsos, e uma paranóide, de conteúdos confabulatórios. A despeito de todas essas observações, é preciso discernir a estrutura de personalidade de uma pessoa que vai participar de um

\footnotetext{
${ }^{1}$ Endereço para correspondência:

Rua Nova Aliança, 164 - Novo Cambuí - 13093-630 - Campinas-SP

E-mail: faustomenon@bol.com.br
} 
depoimento no tribunal do júri, uma vez que, como salienta o autor do livro, se partimos de uma mentira, olharemos uma mentira.

Quanto aos capítulos décimo primeiro, décimo segundo e décimo terceiro, o autor cita algumas técnicas e testes para o conhecimento do funcionamento psíquico. Preocupando-se com essa linha de raciocínio, Mira y López comenta sobre os principais serviços de atendimento psiquiátrico, social e psicológico, assim como os modos de readaptação e de convivência entre os internos sentenciados pela justiça. Já nos capítulos décimo quarto e décimo quinto, embasado em parte nos capítulos anteriores, o autor retoma a idéia de se formar um conhecimento teórico-científico e terapêutico, a fim de classificar e compreender melhor a conduta psicológica do interno no seu processo de ajustamento e de cumprimento da pena. Tudo isso com o uso acrescido de testes e provas materiais, ajudando a entender a diferença entre um crime cometido por debilidade mental e aquele em que há uma motivação psicológica para tal ato infracionário.

Finalizando, no último capítulo, décimo sexto, a discussão se resume em um estudo das personalidades humanas. Traz uma série de definições nosológicas de uma série de psicopatologias e as características psicológicas de cada uma em um quadro didático e inteligível, o que é muito bom para o jurista e para o leitor leigo, pois se tende, ainda com certa insistência, a usar no jargão popular alguns comportamentos e estruturas de personalidade para descrever psicologicamente as pessoas (como exemplo, se diz muito por aí: esse é um estressado, aquele é um neurótico), e isso não é correto. Nesse sentido, o livro presta um trabalho de desmistificação do uso desses vocábulos do senso comum àqueles utilizados na psicologia científica.

Em suma, acredita-se que o livro comprova uma qualidade ímpar em procurar descrever, com um texto bem articulado e repleto de definições claras e objetivas, alguns conceitos-chave da psicologia dentro de um enfoque estritamente jurídico. Embora, de acordo com o autor, o livro esteja voltado, em um primeiro momento, para o profissional que atua especificamente na área de legislação, a citar, advogados, promotores e juízes, pode-se sugeri-lo, a alunos e psicólogos, no exercício da prática clínica e institucional, como nas varas da família e da criança, notadamente ambientado pela psicologia jurídica.

Recebida em setembro de 2006 Reformulada em outubro de 2006 Aprovada em outubro de 2006

Sobre o autor:

Fausto Eduardo Menon Pinto é psicólogo pela Universidade São Francisco/Itatiba, mestre em Educação pela FE/Unicamp e psicólogo da Prefeitura Municipal de Descalvado/São Paulo. 